\title{
Geometry Concept on the Motifs of Woven Fabric in Kefamenanu Community
}

\author{
Yohanis Ndapa Deda ${ }^{1)}$, Stanislaus Amsikan ${ }^{1)}$ \\ 1) Department of Mathematics Education, Universitas Timor \\ Corresponding author: yndapadeda@gmail.com
}

\begin{abstract}
For the Kefamenanu community, the motif serves as the identity of the person who wears it. Nevertheless, the woven fabric must be present at cultural occasions, welcoming guests, and death ceremonies. The motifs of traditional woven fabric have not been developed by teachers to discuss the link between mathematics and local wisdom. The purpose of this research is to define and describe the mathematical concept of the motifs woven fabric to the students of primary and junior high schools. The present study uses a descriptive qualitative method to explain the geometry concept on the motifs of woven fabric. The ethnographic approach is also employed as an empirical and theoretical approach to provide description and analysis about a culture based on intensive field work. Collecting data were conducted using interviews and documentation. Interviews were conducted with several informants selected based on the consideration of researcher and suggestion by previous informant. Documentation was done using video recordings and photos. The results show the geometry concept of the motifs of woven fabric, such as reflection, rotation, translation, repetition, triangle and quadrilateral. The motifs of woven fabric owned by the Kefamenanu community contain particular local wisdom and are potentially used to convey the geometry concept in mathematics for primary and junior high schools.
\end{abstract}

Keywords: Geometry concept, Woven fabric, Motifs, Kefamenanu community

Received: $5^{\text {th }}$ June 2018; Revised: 18 ${ }^{\text {th }}$ December 2018; Accepted: 17th January 2019

\section{Introduction}

Kefamenanu community believes that the motifs of traditional woven fabric have local wisdom and particular meaning. The motifs distinguish the arts, cultures, and customs of each districts associated with Biinmafo Kingdoms, and also represent the social status and prestige of a person in the community. Briefly, people can recognize the background or the status of a person from the motifs of woven fabric, namely Buna, Sotis, and Futus.

Moreover, the motifs of Buna, Sotis, and Mapauf, as well as other variations, i.e., Fut bibousa, mafaif elak, sainiut, niknoo, futkolo, and kolouan, signify the unique characteristics of regions, art, culture, and the social status of Kefamenanu Community. For instance, a person who wears the Buna motif or tenun ikat (fut bibousa) in North Central Timor, will be recognized as an Insana or Biboki. Moreover, these two motifs distinguish one's nobility or the members of the kingdom in ceremonies, such as to welcome guest of honor, wedding ceremonies, and the king's funeral ceremonies. Meanwhile, other motifs in Biboki, such as makaif elak, sainiut, niknoo, and futkolo, in general, can be used by anyone, both men and women, at cultural occasions (i.e., 
wedding and funeral ceremonies). Similarly, the variety of motif of tenun ikat or Buna motif, i.e., pasukenat, mak'aif naek, and mak'aif ana from Miomaffo, can be used by anyone, both men and women, in customary rituals (Lela, 2002). Woven fabric is the legacy of the ancestors of the Kefamenanu community especially for daughters as a women's craft. Woven fabric gives a contribution for parents, husbands, children, and family. Woven fabric is important because it aims to help the needs of the family and at once demonstrated skill and art that is inside of wife or daughter (La'a \& Suwartiningsih, 2013).

Motifs of woven fabric is very important to associate with math because in the made process requires the ability to calculate and measure the length and width of the woven fabric with right, predicts the length of time the manufacture of woven fabric. In addition woven fabric always worn by the students at the school when examination day of subjects in the arts or arts and culture-laden local culture. From this we could use motifs of woven fabric that exist in the Kefamenanu community and we want to make it's a bridge for linking mathematics concepts with the culture of the students which are known by the students.

Connecting mathematics in school with students' experiences has been an important effort to improve the formal mathematics education. The current demand for higher standards of the classroom effectiveness and the teacher accountability leads practitioners to seek for the requirements to become more knowledgeable about their students' personal experiences, particularly as the research continues to demonstrate that community and culture are powerful contributors for students to be successful in school (Brian Greer et al, 2009).

The problem in the process of learning mathematics in primary and junior high schools, particularly in Kefamenanu district is mainly related with the perception of students in learning mathematics. Most students perceive that mathematics is abstract, difficult to understand, and unpractical or there is a gap between mathematics as a subject and students 'real experiences. In fact, there are many local wisdoms of Kefamenanu community that are potential to be developed in order to support the process of learning mathematics in schools. One of them is its traditional woven fabric. Nevertheless, the motifs of woven fabric have not been developed by teachers due to their less creativity to link the learning mathematics and local wisdoms which are known exactly by the students.

The problem of mathematics education in the Kefamenanu community is still happening in many elementary schools that math subjects not taught by teachers in the subjects of mathematics but was taught by master class. As a result the average values of the national standard of the school final examination (UASBN) the last three years are categorized as low. For that, we think it is very important to connect the local wisdom that is already known to the students with mathematics.

Some researchers have investigated the mathematical concepts in relation with the local wisdoms in Indonesia. Arwanto (2017) has revealed the mathematical concepts in Batik Trusmi Cirebon, among them are the concepts of geometry of symmetry, transformation, and congruent. Similarly, Sabilirrosyad (2016) has explored the concepts of geometry in the manufacture of woven fabric of Sasak Ethnic, which showed there are many diagonal axes that emerge from an analysis of the symmetry and repetition of detail on the overall motifs of fabric. Ulum et al (2017) studied the concepts of geometry in the motif of Batik Pasedahan Suropati, namely well point, straight line, curved lines, zigzag line, altitude, line parallel, angles, triangular, rectangle, oval, and symmetry fold, which were discussed in primary school. Risdiyanti and Prahmana (2017) have explored the mathematical concepts, especially the geometry of transformation, in several motifs of 
Yogyakarta Batik. Deda and Disnawati (2017) have investigated the motifs of woven fabric in Kefamenanu Community that become a local wisdom and are continually preserved until today, and have recognized the connection of the motifs with mathematics in general. Therefore, this research will explain four motifs of Kefamenanu woven fabric and the geometry concepts in these motifs. The objective of the research was to explore and characterize mathematical concepts in the motif of woven fabric in Kefamenanu community.

\section{Research Methods}

In this study, data were obtained from several techniques, including field observation, in-depth interview, and documentation. Three craftsmen, one community leader, an anthropologist, and an academic were involved as informants. All informants are over 45 years old. Interviews were conducted to know the motifs of woven fabric in Kefamenanu and their meanings. The interview is conducted two times for the purpose of triangulation of the data. The second interview was done two months after the first interview. The collected data were then analyzed by using a qualitative descriptive method to explain the link between the motifs of woven fabric and mathematics in school (Denzin \& Lincoln, 2011). Meanwhile, the ethnographic approach was employed to obtain the empirical and theoretical data for further description and analysis about the culture of the community based on the intensive field work. This approach is an attempt to disclose how a community imprints the culture as a belief and then practices the culture in the life. Briefly, the culture is in the human mind. Therefore, the function of ethnography is to find and describe the organization of mind (Spradley, 2006).

\section{Results and Discussion}

Data analyzed in the present study were obtained from field observation, in-depth interview, and documentation by involving six informants. Interview was conducted to determine the motifs of woven fabric in Kefamenanu community and their meanings. In general, there are four motifs of woven fabric in Kefamenanu community, namely Buna motif, Futus motif, Sotis motif, and Mapauf motif. Buna and Sotis are the motifs from Insana, Futus is the typical motif from Miomaffo, and Mapauf is the motif from Biboki district. Today, the craftsmen of woven fabric in Kefamenanu commonly possess all of the motifs as their collections and reproduce as well as sell them in the markets around Kefamenanu. The description of the motifs of woven fabric in Kefamenanu community is as follows.

Buna Motif

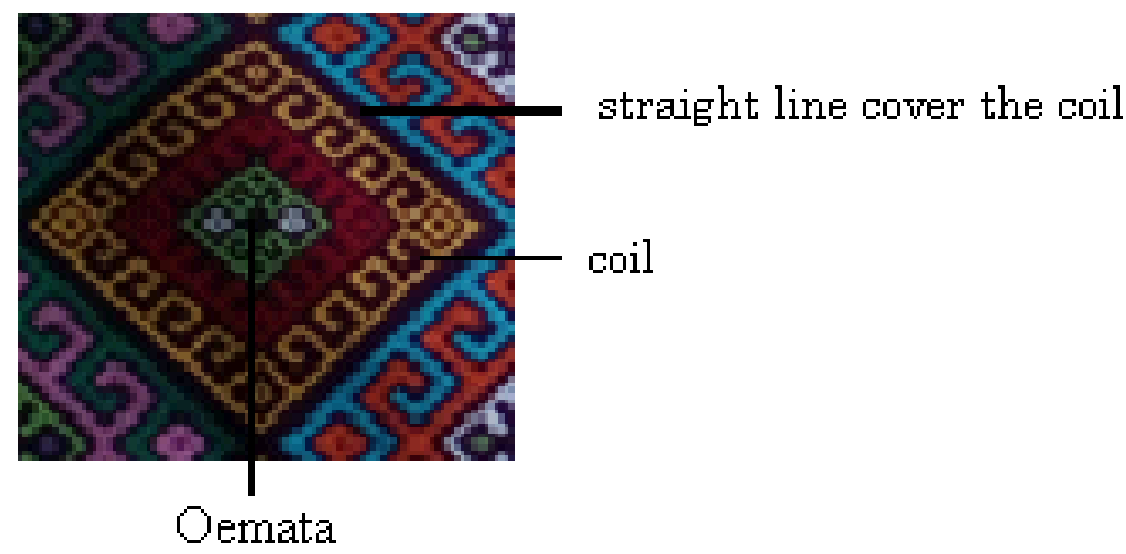

Figure 1. Mak'aif pattern on the Buna motif 
In Buna motif, straight line covers the coil which represents the position of people in Kefamenanu community when performing Tebe dance. Tebe dance is a traditional dance which is performed during a ceremony, i.e., wedding and the birth of a baby. This dance serves as a symbol of happiness in Kefamenanu community. The coil or twist represents the familiarity, togetherness, solidarity and mutual cooperation, in which during the performance of Tebe dance, people hold their hands together and form a circle. Meanwhile, the pattern of smaller circle symbolizes oemata or springs, in which people believe that water is the source of human life. Oemata is derived from Oe and Mata, Oe means water and Mata means springs. Furthermore, there is a special motif called Tais $B a$, which is made for those who violate a customary marriage. In addition, Buna motifs is similar to embroidery or handmade batik in which the outside and inside of the fabric cannot be distinguished.

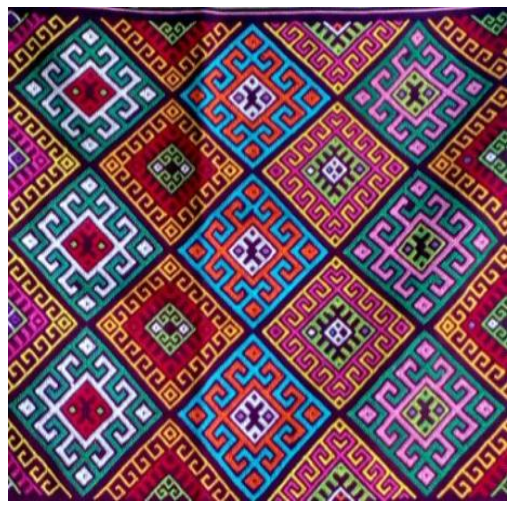

Figure 2. The Buna motif

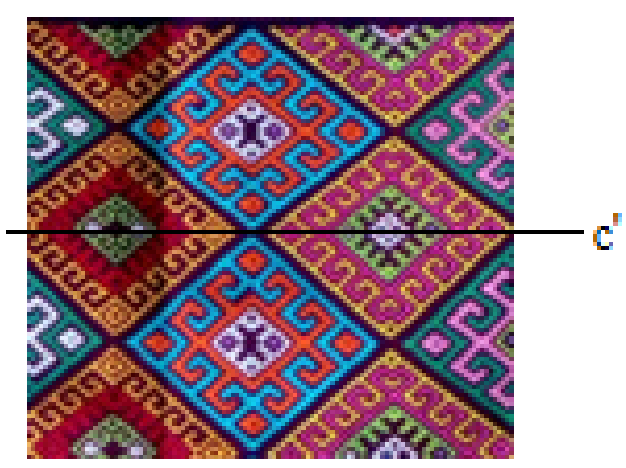

$3 \mathrm{a}$

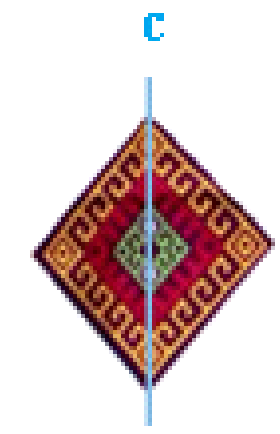

$3 b$

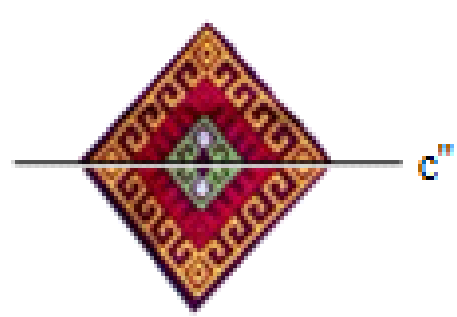

$3 c$

Figure 3. Reflection and Symmetry Concept on the woven of Buna

The pattern of Mak'aif on Figure 3 can be used to introduce the geometry concepts of symmetry and reflection where c' (3a), c (3b), and c" (3c) are the axis of symmetry and mirror line (Dominikus, et al., 2017).

The repetition concept is shown by the vertical repetition of Mak'aif motif (Figure 4). This motif is actually formed from the shifting of the previous motif. Mak'aif on Buna motif can be used as an innovation and material for learning mathematics in primary schools, particularly to elevate the student's knowledge related to the application of mathematics in everyday life and to stimulate students to be more motivated in learning mathematics (Imswatama et al, 2017). 

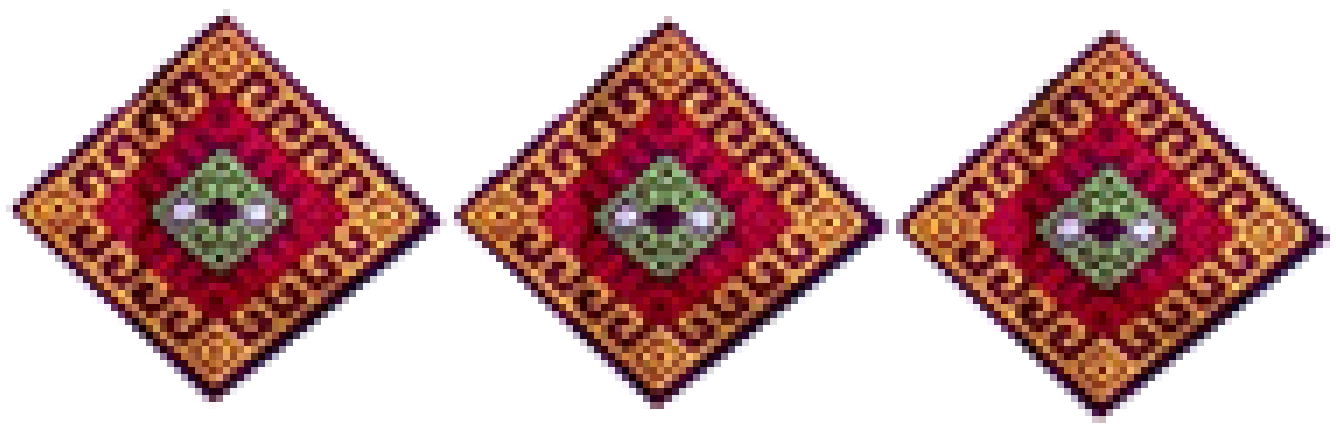

Figure 4. Repetition Concept in Buna motif

\section{Sotis (Lotis) Motif}

Sotis motif is often called Lotis motif. This motif is from Miomafo and Insana regions. In general, the motif is woven by the Miomaffo community. The basic color of Sotis motif is black, which is combined with brown, yellow and red. The process of weaving Sotis uses a stick as the tool to tilt certain threads to create appropriate particular pattern in order to form the desired motif.

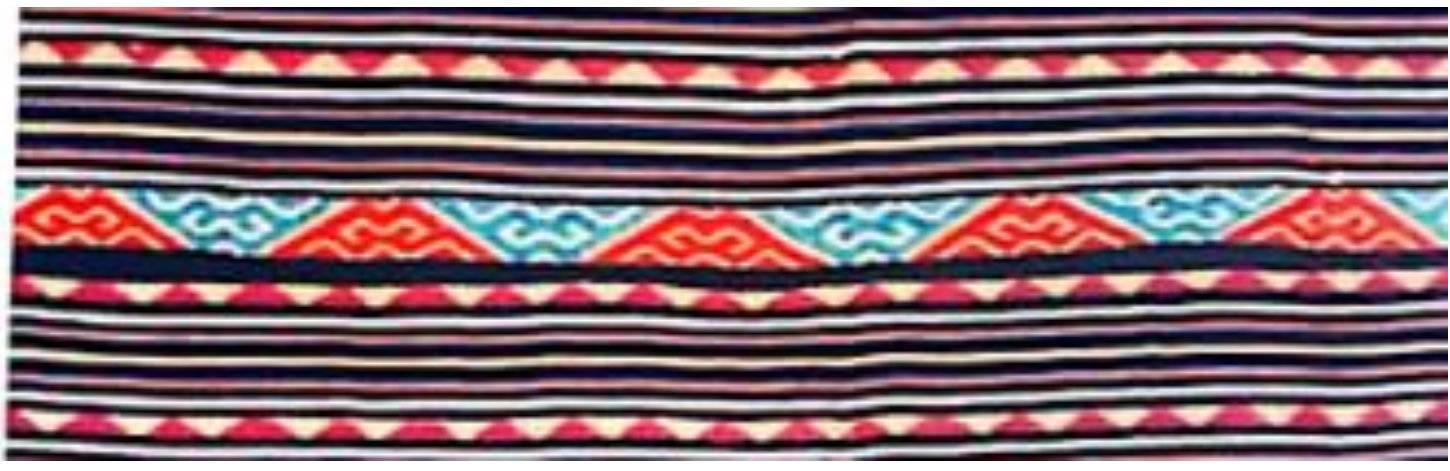

Figure 5. The Sotis motif

Sotis motif can be used in learning mathematics, such as triangle and quadrilateral concepts, in order to understand the properties and area of these concepts. Sotis motif can also be used in learning the reflection concept. Learning mathematics by using real motifs will ease students to understand the concepts (Deda \& Disnawati, 2017).

\section{Futus Motif}

In general, Futus motif of woven fabric is used by the Biboki community. Nevertheless, this motif is also popular and woven by Miomaffo and Insana communities. Futus motif uses the basic colours of black and red and accentuated by blue and yellow colours. Futus motif is also known as kain tenun ikat because the threads are bounded and dipped in natural dye. 


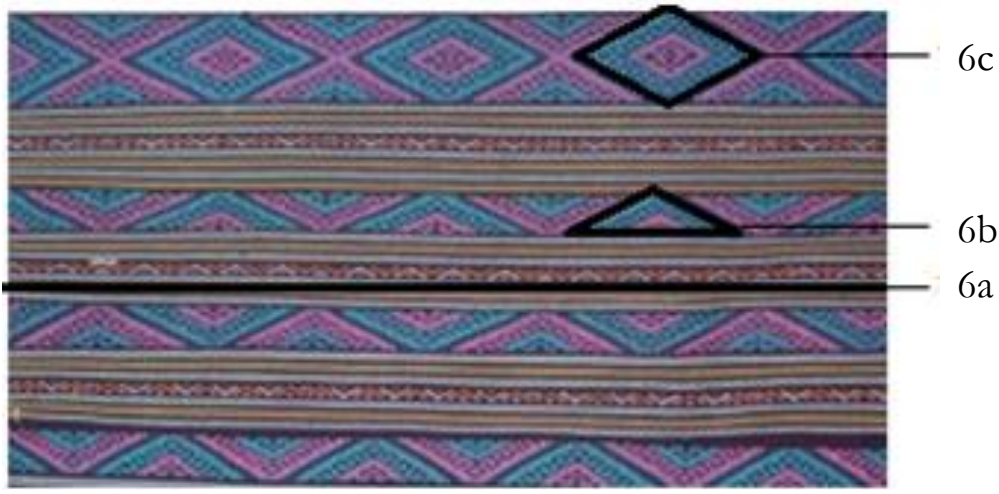

Figure 6. The Futus motif

The motifs of woven fabric in Kefamenanu community are cultural assets that are potentially used as an alternative in learning mathematics, in which it appears that culture can be one of the alternatives in learning mathematics (Turmudi, 2017). Hence, Futus motif will be an alternative way for students to perfectly understand several mathematical concepts, such as the concepts of straight line (6c), triangle (6b), and quadrilateral (6a).

\section{Mapauf Motif}

Mapauf motif of woven fabric is generally created by the east Miomaffo community in Bikomi district. The basic colours of Mapauf motif are red and blue. In addition, there are several patterns in Mapauf motif, such as pattern of fish, trees, gecko, butterfly, and flowers. The process of weaving Mapauf motif uses mal (picture) in which model or form is used to produce the desirable motif.

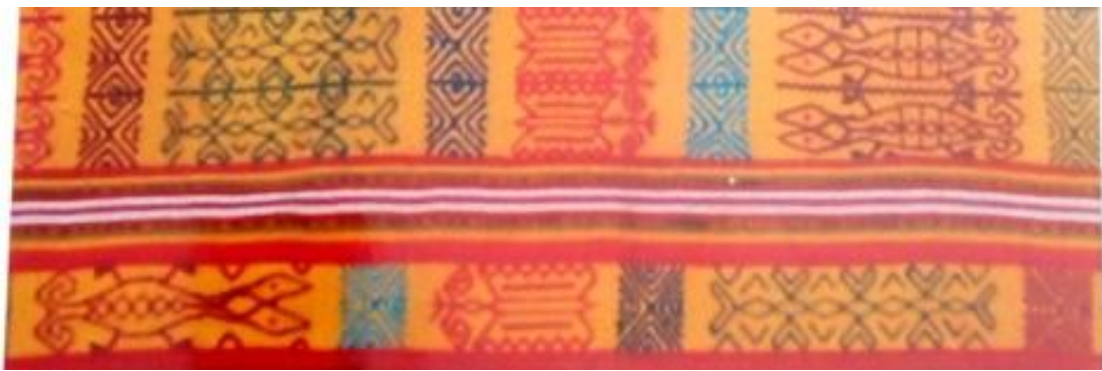

Figure 7. The Mapauf motif

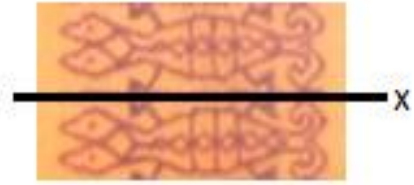

$8 \mathrm{a}$

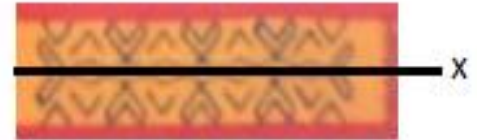

$8 \mathrm{~b}$

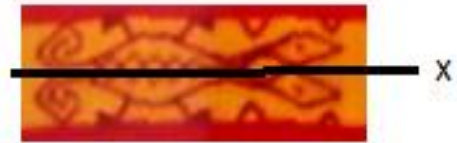

$8 \mathrm{c}$

Figure 8. Reflection and symmetry concept on the Mapauf motif

The Mapauf motif on Figure 8a, b, and c, can be used as an introduction of the concept of symmetry and reflection, where line $\mathrm{x}$ is the axis of symmetry and mirror line. Furthermore, the motif is reflected by the line $\mathrm{x}$ to form other motifs.

The four motifs of woven fabric can be used by teachers to assist students in understanding the concept of the translation or reflection where a motif is the result of the shifting of another motif. In addition to the concept of geometry, the motifs of 
woven fabric in Kefamenanu community can also be used to calculate the area of 2 dimensional shapes.

Some of the mathematical concepts can be juxtaposed with the mathematical school subjects that exist on the Motif of woven fabric in Kefamenanu society. Those concepts are straight lines, parallel lines, triangle, rectangle, translation, reflection, and repetition. By knowing the relationship between school mathematics and local wisdom, can help the teacher to design learning materials based on the context of the Motif of woven fabric.

\section{Conclusion}

The motifs of woven fabric in Kefamenanu community contain local wisdom and can be used to introduce the geometry concept, such as reflection, rotation, translation, and repetition, to students of primary and junior high schools. In addition, the motifs of woven fabric can be used to understand the properties of triangle and quadrilateral, as well as the area of quadrilateral in mathematics. Further studies to investigate the motifs of woven fabric in Kefamenanu community as a material in learning mathematics are required.

\section{Acknowledgement}

The authors would like to thank LPPM Universitas Timor for the financial support for this research.

\section{Bibliography}

Abi, A. M. (2016). Integrasi etnomatematika dalam kurikulum matematika sekolah. JPMI Jumal Pendidikan Matematika Indonesia, 1(1),1-6). Singkawang: STKIP Singkawang.

Amsikan, S., \& Nahak, S. (2017). Hubungan konsep Ruang Ume Kbubu Desa Kaenbaun Kabupaten Timor Tengah Utara dengan konsep geometri. Prosiding KNPM II, 2017,pp.168-175. Surakarta: UMS Surakarta.

Arwanto, (2017). Eksplorasi etnomatematika Batik Trusmi Cirebon untuk mengungkap nilai filosofi dan konsep matematis. Phenomenon Jurnal Pendidikan MIP A, 7(1), 4049). Semarang: State Islamic University Walisongo.

Deda, Y. N., \& Disnawati, H. (2017). Hubungan motif kain tenun masyarakat Suku Dawan - Timor dengan matematika sekolah. Prosiding KNPM II, 2017, pp.201209. Surakarta: UMS Surakarta.

Denzin, N.K., \& Lincoln, Y.S. (Eds.). (2011). Handbook of qualitative research fourth edition. California: Sage Publication.

Dominikus, W.S., Nusasantara, T., Subanji, \& Muksar, M. (2017). Ethnomathematical Ideas in the Weaving Practice of Adonara Society. Journal of Mathematics and Culture, 11(4), 83-95. USA: JMC.

Greer, B. (2009). Culturally responsive mathematics education. Oxford: Routledge Taylor and Francir Group.

Helsa,Y. \& Hartono,Y. (2014). Designing reflection and symetry by using math traditional dance in primary school. Journal on Mathematics Education (IndoMS-JME), 2(1), 79-94. Palembang: IndoMS.

La'a, A. S. \& Suwartiningsih, S. (2013). Makna tenun ikat bagi perempuan. KRITIS Jurnal Studi Pembangunan Interdisiplin, 22(1), 21-40. Salatiga: Perpustakaan Daerah Kota Salatiga.

Lela, L. (2002). Katalog Tenunan Kabupaten Timor Tengah Utara. Kefamenanu: Dewan Kerajinan Nasional Daerah Timor Tengah Utara.

Muhtadi, D., Sukirwan, Warsito, \& Prahmana, R., C., I. (2017). Sundanese ethnomathematics: mathematical activities in estimating, measuring, and making 
patterns. Journal on Mathematics Education (IndoMS-JME), 8(2), 185-198. Palembang: IndoMS.

Putri, L., I. (2017). Eksplorasi etnomatematika kesenian rebana sebagai sumber belajar matematika pada jenjang MI. Jurnal Ilmiah PENDIDIKAN DASAR, 4(1), 21-31. Bali: Undiksha.

Risdiyanti, I., \& Prahmana, R. C. I. (2017). Ethnomathematics: Exploration in javanese culture. AD INTERCOMME IOP Publishing IOP Conf. Series: Journal of Physics: Conf. Series 2017. Ahmad Dahlan University.

Rosa, M. \& Orey, D.C. (2011). Ethnomathematics: the cultural aspects of mathematics. Revista Latino Americana de Etnomatematica, 4(2), 32-54. Colombia: Sistema de Información Científica.

Sabilirrosyad, (2016). Ethnomatics Sasak: Eksplorasi geometri tenun suku Sasak Surakarta dan implikasinya untuk pembelajaran. JURNAL TATSQIF Jurnal Pemikiran dan Penelitian Pendidikan, 4(1), 49-65. Mataram: IAIN Mataram.

Snipes, V. \& Moses, P. (2001). Linking mathematics and culture to teach geometry concepts. LTM Journal Louisiana Association of Teacher of Mathematics. Retrieved www.lamath.org/journal/Vol1/LinkCult

Spradley, \& James, P. (2006). Metode Etnografi. Yogyakarta: Tiara Wacana.

Turmudi. (2017). Kajian Etnomatematika: belajar matematika dengan Melibatkan Unsur Budaya. Prosiding Seminar Nasional Etnomatnesia 2017, 38-53. Yogyakarta: Universitas Sarjanawiyata Tamansiswa.

Ulum, B., Budiarto, M. T., \& Ekawati, R. (2017). Etnomatematika Pasuruan: Eksplorasi Geometri Untuk Sekolah Dasar Pada Motif Batik Pasedahan Suropati. Prosiding SIMaNIs (Seminar Nasional Integrasi Matematika dan Nilai Islami) 2017, 70-78. Malang: UIN Maulana Malik Ibrahim Malang. 